\title{
Szerkesztői kommentár
}

A magyar egészségügyben szükség van megbízható adatokra. Az Orvosi Hetilap aktuális száma a második tematikus összeállítás, amely a betegregiszterekkel foglalkozik. A három évvel ezelőtti számban bemutattuk a jelentősebb hazai betegregisztereket. Jelen alkalommal aktuális eredményeket szeretnénk ismertetni, olyan adatokat, amelyek alapját képezhetik egészségpolitikai döntéseknek. Évtizedek óta tapasztaljuk, hogy az egészségügyet érintő intézkedések ritkán támaszthatók alá a napi gyakorlatból származó, hiteles adatokkal. A regiszterek múködése lehetőséget kínál a változásra.

Az évek óta országos adatokat gyüjtő Nemzeti Rákregiszter és a Nemzeti Szívinfarktus Regiszter eredményei alkalmasak az ellátás helyzetének megítélésére, a minőségi kontrollra. Mindkét regiszter aktuális adatai olvashatók ebben az összeállításban.

Az olvasók figyelmébe ajánlom a Magyar Szivelégtelenség Regiszter vizsgálatot bemutató közleményt, amely két okból is figyelemre méltó: a szívelégtelenség előfordulási gyakorisága nő, az egyik leggyakoribb kórházi ellátást igénylő, jelentős halálozással járó betegség. Az egy évvel ezelőtt - néhány centrum részvételével - megkezdett munka alapját képezheti egy országos lefedettségü regiszternek és egy olyan gondozási rendszernek, amely - nemzetközi tapasztalatok alapján - javítani képes ezen rossz életkilátású betegcsoport prognózisát.

A szívizombetegségekkel foglalkozó cardiomyopathiás és ioncsatorna-betegek regisztere ritkán előforduló kardiológiai kórképek adatait gyưjti, vizsgálja a betegség klinikai formáit, a genetikai adatokat, családszűrést végez és adatokat szolgáltat a késői kórlefolyásról. Jelentőségét az adja, hogy az egységesen kivizsgált és dokumentált betegcsoport adatain keresztül megismerjük a patomechanizmus és a prognózist befolyásoló tényezőket, az informatikai rendszere pedig alkalmas más centrumok adatainak fogadására.

A coronariarendszer komputertomográfiás vizsgálata - Országos Plakk Regiszter és Adatbázis (OPeRA) címú összeállításban egy teljesen új megközelítésű - jelenleg egy centrumban múködő - regiszterrel ismerkedhetünk meg. A regiszter munkatársai azt kívánják vizsgálni, hogy a koszorúér patológiás eltérései (plakk) hogyan osztályozhatók, milyen módon jellemezhetők azok az érelváltozások, amelyek közvetlen veszélyt jelentenek a súlyos cardialis események (szívinfarktus, hirtelen halál) szempontjából. A multicentrikus részvételre tervezett adatbázis megteremti a hazai coronaria-CT-vizsgálatok egységes értékelésének lehetőségét.

A Myeloproliferativ Neoplasia Magyarországi Regiszter adataiból a szerzők az essentialis thrombocytaemiás betegek adatait elemzik. Többéves utánkövetéssel vizsgálják a thromboemboliás szövődmények előfordulását befolyásoló tényezők jelentőségét és a különböző kezelési modalitások eredményességét.

Őszintén remélem, hogy a most közreadott tematikus szám elnyeri az olvasók érdeklődését. Meggyőzi az olvasókat - esetleg a döntéshozókat -, hogy betegregiszterekre szükség van, ha valós adatokat kívánunk megismerni munkánk eredményességéről. Az összeállításban a kardiológiai témák dominálnak, ez nem a szerkesztő elfogultságát tükrözi, hanem a szakmát művelő kollégák elhivatottságát jelzi, a betegellátás javítása és a minőségbiztosítás kérdésében.

A tematikus szám vendégszerkesztőjeként köszönöm az Orvosi Hetilap főszerkesztőjének és szerkesztőségének, hogy támogatták a kéziratok megjelentetését.

Jánosi András dr., vendégszerkesztő 